increases in solar radiation, we should have increases in evaporation from the sea and consequent increases in precipitation in the colder regions of the earth. The interglacial periods would be associated with few sunspots and reduced evaporation and precipitation. During them the glaciers would gradually shrink, exposing great masses of boulder clay which would be washed away by the melting ice and deposited as thin bands of sand and clay elsewhere. Visitors to Switzerland who have noted the milk-white appearance of the Upper Rhone during the summer months will need no further reminder of the nature of the water issuing from the foot of a melting glacier.

Coleman, in his book ("Ice Ages"), mentions the continental drift theory but withholds his assent on the ground of the colossal forces necessarily assumed, which he holds to be incredible. But, as Sir Thomas Holland has pointed out, there is no possible escape from the conclusion that the tearing asunder of primitive continents and their drifting apart really did take place. Actually Greenland has been caught in the very act of drifting. A Danish observer, Oersted, has measured the change in longitude of a station in the extreme south of Greenland between the years 1922 and 1932. The amount determined was 600 feet, that is, 60 feet a year. If we calculate back 100,000 years, we find that Greenland must have then been lying close to Norway. Now from observations on the annual layers of silt deposited every summer by the streams fed by the melting ice, it has been ascertained that it is about 13,000 years since an ice-sheet covered the whole of Sweden. The great Würmian glaciation may have lasted 100,000 years to judge from the enormous extent of the boulder clay which it produced. On the west coast of Wales the clay and boulders carried by this icesheet which had crossed the Irish Sea were piled up to a depth of 200 feet. A period of 120,000 years would carry us back into the interglacial period between the Reiss and the Würm glaciations-the time indeed when Neanderthal man flourished.

When the exposed boulder clay became dried out it broke up into dust, and this under the name of 'loess' was blown about by the wind. In central China this loess is piled up to a depth of hundreds of feet. A similar degradation of soil into dust is taking place in North America.

We must conclude with a few words about the bearing of these climatic changes on evolution. What changes the Pre-Cambrian ice-epoch produced in life we do not know, but the researches of Prof. D. M. S. Watson and Dr. R. Broom on mammals prove that the growth of cold-blooded reptiles into warm-blooded mammals began directly after the Gondwana ice-age. During the Miocene epoch a continuous forest stretched across the Old World from the shores of France to the coast of China. Bones and skulls show that this forest was inhabited by the higher apes, the direct precursors of man; but in Pliocene times a northern drift of the old Africa and the Deccan of India began which, impinging on the tableland of central Asia, raised up the enormous barriers of the Himalayas and associated mountains and in Europe the Alpine chain.

Thus the ape population was cut into a northern and a southern group: the latter continued to find its living in the forest, where remnants of it persist as the chimpanzees, gorillas, orangs and gibbons of to-day. The northern group, however, had to face a more severe climate, the first beginning, in fact, of the Pleistocene ice-age. The forest gave way to steppe and the apes had to change their habits to hunting on the ground, and primitive hunting man was born.

Thus there would be much truth in the epigram : the Gondwana ice-age produced the warm-blooded mammals, the Pleistocene ice-age produced man.

\title{
The Organization of Knowledge
}

$\mathrm{T}$ HE unprecedented progress of science and its applications during the last hundred years has given rise to a flood of literature, the magnitude of which has dulled our senses into a sort of acquiescence. About two thousand new volumes on scientific subjects are issued annually by British publishers, while the number of scientific papers published in a year throughout the world has been estimated to amount to three quarters of a million. A century ago, a scientific worker was expected and able to digest for himself practically the whole of the original literature of his subject. To-day it is with difficulty that he can keep abreast of a particular part of it, even with the aid of a new type of abstracting and indexing literature, which has been evolved specially for this purpose. If he would seek to know what discoveries, which might be useful to him, have been recorded in other branches of his own and different sciences, he must depend entirely upon such services. 
The need for the evolution of this new kind of library aide memoire is now universally recognized. Indeed, a terrifying sense of insufficient mental material is beginning to dawn upon the minds of a few individuals, particularly of those whose special interest lies in the domain of the applications of science to the benefit of mankind. For that is not knowledge which we do not know where to find. Nevertheless, the present deficiencies and lack of organization in this new research service seem in danger of being overlooked, and the necessity of assembling and perfecting this mechanism of knowledge is not realized, although, perhaps, as much as fifty per cent of modern technical research could be saved if complete information as to recorded data could be made available.

We need to realize, as Mr. Maynard Keynes has expressed it, that "we do not even know what is to be known", and straightway to set about in earnest to organize a master-key to the vast storehouse of recorded information. This is not a question of merely making bibliographies, but of providing a complete bibliographical service, so that anyone can ascertain immediately exactly what information has been recorded on every new question as it arises.

It was for the purpose of the solution of this important problem that the International Institute of Bibliography was founded by an international conference in Brussels in 1895. To this end the Institute has worked for more than forty years. The data concerning the problem have been ascertained, principles have been evolved, much progress has been made, progress which increases year by year. National sections of the Institute have been founded in many countries. The Institute has sought, with growing success, to link together all those, both institutions and individuals, whose interest lies in the collection, classification and dissemination of information. Last year, at a World Congress on Documentation, held in Paris by invitation of the French Government, and attended by representatives of thirty Governments and forty international organizations, the Institute was recognized unanimously as the controlling international bibliographical organization, its federative character being expressed in the decision to change its name to International Federation for Documentation.

At this meeting it was decided to hold in England the Fourteenth International ConFERENCE OF THE INTERNational Federation FOR DOCUMENTATION.

The British Government has extended its patronage, and Sir William Bragg, president of the Royal Society, has accepted the presidency. The chairman of the organizing committee is Dr. S. C. Bradford. The Conference will be held at Lady
Margaret Hall, Oxford, on September 21-25, followed by final sessions at the Science Museum, South Kensington, S.W.7, on September 26. Advantage of the meeting being in England has been taken to include joint sessions with the annual conference of the Association of Special Libraries and Information Bureaux. Eminent representatives of every branch of intellectual activity have given their support to the Conference. Papers will be read by leading authorities from many countries. Successful as has been the work of the International Federation in the past, it has tended rather to confine itself to making more easily available the literature relative to the natural sciences and their applications. Opportunity will be taken of the forthcoming Conference to endeavour to secure greater collaboration with bibliographers in other fields, such as those of history, archive work and economics. Special attention to these subjects will be given in the papers to be read.

Among the hundred or more papers which have been offered to the Conference we notice the following: Grundsätzliches zur Frage der Vereinheitlichung und Nornung auf dem Gebiete des chemischen Referatenwesens, by Dr. Maximilian Pflücke, chief editor of the Chemisches Zentralblatt; Bibliographical tools from the user's point of view, by Dr. J. Holmstrom ; Le travail bibliographique internationale dans les domaines des études historiques, by P. Carron, director of the Archives de France; Archives in their relation to other forms of documentation, by Hilary Jenkinson, secretary of the Public Records Office; On the present state of documentation in Switzer. land, by W. Janicki, past president of the Swiss National Section of the International Federation for Documentation; and The current German situation in the field of practical documentation, by Dr. A. Predeek, chief librarian of the Technische Hochschule, Berlin.

The titles of the papers to be communicated, together with full information concerning the Conference, are given in the preliminary programme, a copy of which can be obtained on application to the secretary, Miss M. Gosset, Science Library, Science Museum, South Kensington, S.W.7. The programme includes visits to some of the many interesting places in the neighbourhood of Oxford, together with other social functions, such as receptions by the Vice-Chancellor and the Mayor, and a Government banquet in the beautiful hall of Christ Church.

All who appreciate the vital importance of the organization of information will realize that the visit of this Conference to England provides a special opportunity of assisting in the discussion and development of a service which feeds the roots of intellectual progress. 